\section{Model for Grampian tract evolution}

DEWEY and Shackleton's stimulating and provocative model for the evolution of the Grampian tract of the CaledonideAppalachian orogen ${ }^{1}$ postulates subduction towards the south-east between about $510 \mathrm{Myr}$ BP and at least $470 \mathrm{Myr}$ BP. As a result, they reject previous suggestions that the extensive layered mafic and ultramafic intrusions of Connemara and northeast Scotland were emplaced (at 485500 Myr BP) above a north-west-dipping subduction zone and formed the roots of Andean-type volcanic $\operatorname{arcs}^{2}$ or the lower parts of batholiths, subsequently removed during Upper Ordovician erosion ${ }^{3}$. The more mafic of these plutons contain cumulus assemblages of the minerals olivine plus chromite, followed by magnesian ortho- and clinopyroxene, very calcic plagioclase, and interstitial primary amphibole-inferred to precipitate at deep-crust levels within island arcs from subduction-related, silica-saturated hydrous magnesian magmas ${ }^{4,5}$.

Figure 1 shows normalized incompatible trace elements in samples of each complex that have essentially escaped both the interaction with upper-crust metasediments and the Grampian deformation and metamorphism that affects most of them. Subduction-related basalts from Japan and Vanuatu are also plotted in Fig. 1. The essential similarities of many inter-element ratios between these modern circum-Pacific island-arc lavas and the Ordovician plutons are clear. As a group, the trace-element patterns (Fig. 1) of these samples are characteristic of subductionrelated magmas worldwide and are quite different from those erupted in other tectonic environments, such as strike-slip pull-aparts, which Dewey and Shackleton suggest as an alternative. A Recent basanite from Dish Hill, Southern California (Fig. 1) is a typical example of the predominant type of basic magmatism in the south-west USA, extruded since the inception of a strike-slip plate boundary in this region.

Dewey and Shackleton have commented ${ }^{1}$ that their "model is invalid, at least for the British Isles", if these Lower Ordovician plutons are subductionrelated. I agree that more research is needed, but nevertheless, emphasize that there is already sufficient knowledge of the geochemistry of Lower Ordovician magmatism in the Caledonian-Appalachian orogen that the data from this approach cannot be ignored when constructing overall models.

\section{R. N. THOMPSON}

Department of Geology,

Imperial College,

London $S W 72 B P, U K$
Fig. 1 Normalized ${ }^{3}$ trace-element plot. Small arrows indicate element abundances below detection limits. The log scale represents: Abundance (mass) of each element in rock/Abundance in chondrites. Data are from refs 3 and 6 .

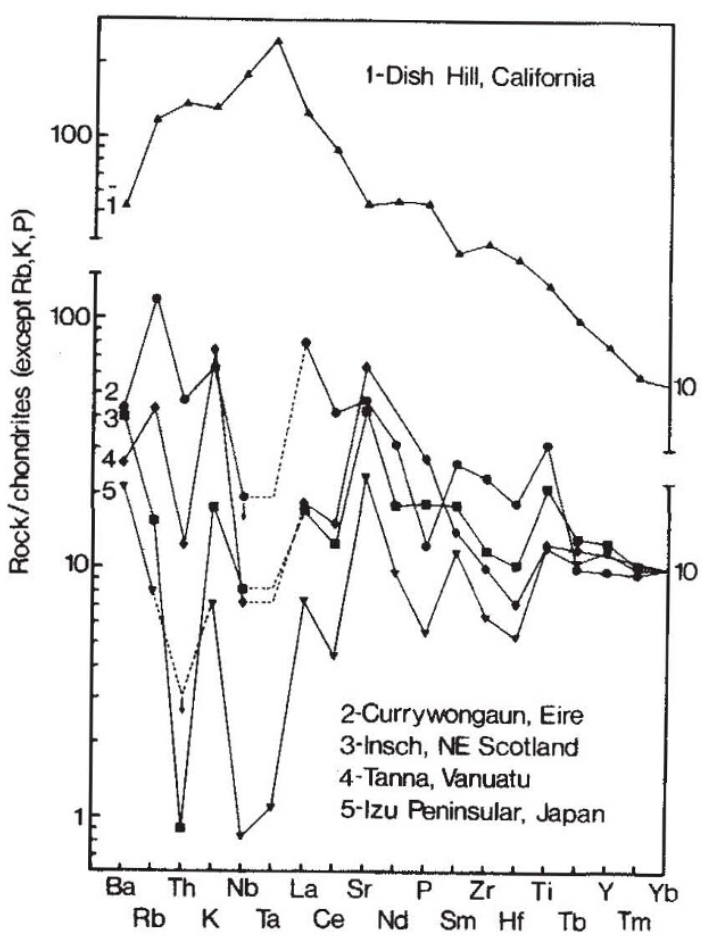

1. Dewey, J. F. \& Shackleton, R. M. Nature 312, 115-121 1984).

2. Yardley, B. W. D., Vine, F. J. \& Baldwin, C. T. J. geol, Soc Lond. 139, 457-463 (1982)

3. Thompson, R. N., Morrison, M. A., Hendry, G. L. \& Parry, S. J. Phil. Trans. R. Soc. A310, 549-590 (1984).

4. Leake, B. E. Geol. J. spec. Publ. 10, 221-248 (1978).

5. Perfit, M. R., Gust, D. A., Bence, A. E., Arculus, R. J. \& Taylor, S. R. Chem. Geol. 30, 227-256 (1980).

6. Dupuy, C. et al. Earth planet. Sci. Lett. 60, 207-225 (1982).

DEWEY AND SHACKLETON REPLYWe thank Thompson for his geochemical data and conclusions and agree that a successful model for the evolution of the Grampian tract must account for geochemical and petrological data. Clearly, from the perspective of incompatible element pattern recognition, the Connemara and Banffshire intrusions are similar to the magmatic rocks of some modern arcs, but our lack of geochemical expertise disqualifies us from commenting on that data. However, we note that calcalkaline magmatism occurs in a wide variety of non-arc settings including collisional environments such as eastern Anatolia. An important mechanism in collisional orogens is lithospheric delamination $^{1}$, which allows hot fertile mantle to gain access to levels as high as the base of a thickened crust. This causes rapid uplift and denudation and a surge of mafic magmatism and possibly partial melting of a mafic lower crust. We suggest that such a mechanism was responsible for the Grampian mafic intrusions. Our use of the term 'pull-apart' is simply kinematic and does not imply a particular regional tectonic setting. Pull-aparts in strike-slip systems occur in almost every type of regional tectonic environment including island arcs. In collisional systems, they may localize calc-alkaline magmatic rocks (for example, Erzinçan basin on the North Anatolian Fault). A particular problem with the Connemara intrusions is that we know little of their original form and intrusive mechanism, though they appear to have a regionally disrupted sheet-like form. A particular problem in considering the intrusions as arc roots is that they were latest stages of shortening. A West Pacific model, therefore, seems inappropriate because most of the West Pacific is in deviatoric tension where shortening is rare.

Lastly, the model is developed largely from data for Newfoundland where it seems difficult to refute, and then extrapolated to the British Isles. It is quite certain that the obduction model in its simplest form cannot account for the Taconian events of the Appalachians south of Quebec, because the tell-tale mafic detritus, particularly chromite, is virtually absent from the Taconic flysch belt in the US Appalachians. Hence, although it is also possible that the obduction model is inappropriate for the early Caledonides and is unique to the Canadian Appalachians, we cannot yet think of a better model.

J. F. DEWEY
R. M. SHACKLETON
Department of Geological Science,
University of Durham,
South Rd, Durham DM1 3LE, UK

1. Bird, P. J. geophys. Res. 83, 4975-4987 (1978). intruded into a pile of nappes during the 